\title{
ВЛИЯНИЕ БИОФУНГИЦИДОВ НА РАЗВИТИЕ ВОЗБУДИТЕЛЕЙ АЛЬТЕРНАРИОЗА КАРТОФЕЛЯ
}

\author{
${ }^{1}$ Мельник A.T., ${ }^{2}$ Кирик Н.H.
}

${ }^{l}$ Украинская научно- исследовательская станиия карантина растений ИЗР НААН Ул. Научная 4, с. Бояны Новоселиикого района Черновичкая область, 63021, Украина ${ }^{2}$ Национальный университет биоресурсов и природоиспользования Украины Киев ул. Героев Обороны, 13, учебньй корпус №4, к.52,03041, Украина allona_melnik@ukr.net

Abstract: The biological preparations: Planrise, Trychodermin, Phytodoctor on alternaria blight pathogen developing results were proposed. Their inhibiting action were proven by experimental 
way. The highest inhibiting growing was observed in variant with $10 \%$ solution Planrise and Trychodermin. It was consisted of 25,0 and 29,0 mm, respectively.

Key words: pathogen, potato, alternaria blight, efficiency, biofungicides.

\section{Введение}

Альтернариоз (макроспориоз, сухая пятнистость)-вредное заболевание грибной природы, получившее значительное ежегодное распространение по территории Украины и наносит большой экономический урон картофелеводству. Заболевание снижает урожайность культуры до $50 \%$. Наблюдается количественное снижение урожая, ухудшение его качества, лежкости и ухудшения фитосанитарного состояния агроценозов. [1,5,6]. Поражение площадей картофеля происходит из-за падения культуры земледелия, а именно: бесконтрольное внесение удобрения и систем подпитки, невыполнение агротехнических требований касательно севооборота, оптимальных сроков посадки, отсутствие качественного семенного материала, неблагоприятных метеорологических условий и поражение патогенными организмами грибного происхождения $[4,5]$.

Актуально- внедрения новейших бтотехнологий, основанных на использовании микробиологических препаратов, позволит повысить устойчивость растений к фитопатогенам, продуктивность и качество продукции, а также защитить окружающую среду от негативного влияния антропогенных факторов: загрязнение подземных вод, негативного влияния на рост и развитие растений и нарушение микробиологических процесов в почве $[2,4]$.

С этой целью проводились исследования по изучению эффективности использования биологических препаратов на возбудителей альтернариоза картофеля.

\section{Материалы и методы исследований}

Исследования проводились на базе лабораторий микробиологических исследований биоагентов Украинской научно- исследовательской станции карантина растений ИЗР НААН на протяжении 2018-2020 гг., с помощью закладывания опытов и проведения лабораторных анализов. Выделение возбудителей в чистую культуру проводили согласно стандартных методик $[1,6]$. Возбудитель альтернариоза картофеля Alternaria alternata (Keissler) был объектом исследований. В процессе эксперимента использовались следующие биоологические препараты Планриз, Триходермин, ФитоДоктор.

В качестве питательной среды использовали КГА, после охлаждения добавляли раствор препаратов в концентрациях 2,5\%, 5\%, $10 \%$. Для контроля использовали чашки с питательной средой, без добавления препаратов.

Рост культуры происходил при температуре $25^{\circ} \mathrm{C}$ в термостате. Наблюдение за ростом и развитием грибных колоний проводился визуально ежедневно, их размер определяли по средним значениям трёх измерений диаметров $[1,3]$.

Планриз- высокоэффективный микробиологический препарат фунгицидного и бактерицидного действия на основе жизнеспособных почвенных (ризосферных) бактерий Pseudomonas fluorescens штамма АР-33, а также продуктов их метаболизма с титром не ниже $3,0 * 10^{9}$ спор на 1 мл препарата. При внесении препарата в почву, бактерии активно заселяют корневую систему растений- питателей, продуцируя ряд веществ: ферменты, фитоалексины, антибиотики, органические кислоты, тем самым ингибируя развитие фитопатогенов со стимулированием роста растений. 
Триходермин- биологический препарат предназначенный для борьбы с комплексом грибных и бактериальных болезней растений. Действующее вещество культуральное вещество, содержащее мицелий гриба- антагониста Trichoderma lignorum. Подавляет рост и развитие грибов рода: Alternaria, Ascochyta, Botrytis, Colletotrichum, Fusarium, Phoma, Phytophtora.

ФитоДоктор- биофунгицид широкого спектра действия для профилактики и лечения комплекса болезней сельскохозяйственных культур, вызванных фитипатогенных грибов и бактерий фитофтороза, мучнистой росы, альтернариоза, ризоктониоза, фузариоза и т.д., изготавливаются на основе живых клеток и спор бактерии Bacillus subtilis (Ehrenberg 1835, Cohn 1872).

\section{Результаты и обсуждения}

Результаты исследований по использованию биологических препаратов показали существенное угнетение роста патогенов при дополнение в питательную среду. $10 \%$ концентрации препарата Планриз и Триходермин. Немного низкие показатели наблюдались при использовании ФитоДоктора.

Лучишие показатели развития (размер колоний составлял 8,3мм) патогенов наблюдались в контрольной среде без внесения препарата. Наибольшее угнетание роста наблюдалось в варианте с 10\% раствором Планриза и Триходермина, соответственно составляло 25,0 и 29,9 мм.

Интенсивность роста Alternaria alternata зависит от концентраций биопрепаратов.

\begin{tabular}{|c|c|c|c|c|}
\hline \multirow{2}{*}{\begin{tabular}{c} 
препарата/концентрации \\
\cline { 2 - 5 }
\end{tabular}} & \multicolumn{5}{|c|}{ Количество суток, после пассажа/диаметр колони, мм. } \\
\cline { 2 - 5 } & 1 & 3 & 5 & 8 \\
\hline Планриз & 9,3 & 50,0 & 72,5 & 83,6 \\
\hline К & 1,0 & 5,0 & 17,1 & 41,4 \\
\hline $2,5 \%$ & 0,2 & 3,7 & 10,4 & 39,0 \\
\hline $5 \%$ & 0 & 0 & 5,0 & 25,0 \\
\hline $10 \%$ & 9,3 & 50,0 & 72,5 & 83,6 \\
\hline Триходермин & 1,7 & 7,6 & 19,2 & 43,0 \\
\hline К & 0,5 & 6,8 & 15,3 & 40,8 \\
\hline $2,5 \%$ & 0 & 0,2 & 7,6 & 29,9 \\
\hline $5 \%$ & 9,3 & 50,0 & 72,5 & 83,6 \\
\hline $10 \%$ & 2,5 & 9,0 & 25,4 & 52,0 \\
\hline ФитоДоктор & 1,2 & 7,4 & 19,6 & 49,5 \\
\hline К & 1,0 & 5,2 & 16,4 & 36,0 \\
\hline $5 \%$ & \multicolumn{5}{|l}{}
\end{tabular}

\section{Выводы}

При использовании пассажей предложенных патогенов в питательной среде, проявилось в замедлении роста и развития при действии Планриза, Триходермина и ФитоДоктора. Наибольшее угнетение роста наблюдалось в варианте с $10 \%$ раствором Планриза и Триходермина, соответственно составляла. 25,0 и 29,9 мм. 


\section{Библиография}

1. Билай В. И. Методы экспериментальной микологии / Под ред. В. И Билай. К.: Наукова думка, 1982.-552c.

2. Калач В. И., Иванюк В.Г. Биологическая эффективность фитофунгицидов против грибных болезней на культуре картофеля в Беларуси. // Биол. защ. раст.- основа стабил.агроэкосис. Мат. Межд.н/п конф. Краснодар: ВНИИБЗР,2004, вып. 2, с. 322-324

3. Мельник А. Т., Кирик М. М., Гунчак В. М. Ріст колоній Alternaria solani (Ell. et Mart.) на різних живильних середовищах за різних температур // Захист і карантин рослин. - 2017. - № $1-3$ - С. 23 - 24.

4. Тихонович И. А., Кожемяков А. П., Чеботарь В. К. Биопрепараты в сельском хозяйстве. Методология и практика применения микроорганизмов в растениеводстве и кормопроизводстве / [ И. А. Тихонович, А. П. Кожемяков, В. К. Чеботарь и др.]. - М.: Россель - хоз ака демия, 2005. - 154 с.

5. Патика В. П., Омельянещъ Т. Г Екологічні основи застосування біологічних засобів захисту рослин як альтернативи хімічним пестицидам / В. П. Патика, Т. Г. Омельянець // Агроекологічний журн. - 2005. - № 2. - С. 21-24.

6. Пат. 100610 UA. МПК: G01N (2015 01), Спосіб визначення стійкості картоплі до Alternaria solani (Ell.et Mart) та Alternaria alternata (Keissler) / Мельник А. Т., Кирик М. М., Зеля А. Г., Гунчак В. М., Тома 3. Г., Зеля Г. В., Кордулян Р. О., Гунчак М. В., Соломійчук ;М.П., № u2013 12800; заявл. 04.11.2013; опубл. 10.08.2015. 